\title{
PERUBAHAN PERSEPSI POLA ASUH PESERTA SETELAH MENGIKUTI PROGRAM SEKOLAH IBU DAN CALON IBU KOTA BANJARMASIN
}

\author{
Difi Dahliana a, 1 , Ika Irayana ${ }^{\text {b, } 2}$ \\ ${ }^{a b}$ Universitas Islam Negeri Antasari Banjarmasin \\ ${ }^{1}$ difidahliana@uin-antasari.ac.id; ${ }^{2}$ ira79yana@gmail.com
}

\section{Informasi artikel \\ Received: \\ Agust 10, 2019. \\ Revised: \\ Agust 22, 2019. \\ Publish :}

September 09, 2019.

Kata kunci:

Perubahan pola asuh

Pola Asuh

Anak

Keywords:

Changes in parenting

Parenting

Children

\begin{abstract}
ABSTRAK
Salah satu upaya yang dilakukan pemerintah kota Banjarmasin untuk memperbaiki pola asuh terhadap anak di masyarakat adalah dengan mengadakan program parenting yang dinamai dengan Sekolah Ibu dan Calon Ibu. Penulis tertarik untuk meneliti apakah setelah mengikuti Sekolah Ibu ada perubahan pola asuh yang lebih baik dari para pesertanya. Oleh karena itu, dilakukan penelitian lapangan yang bersifat kualitatif dengan teknik pengumpulan data melalui angket terbuka. Hasil penelitian menunjukkan adanya perubahan pola asuh dari otoriter menjadi demokratis setelah peserta mengikuti Sekolah Ibu dan Calon Ibu Kota Banjarmasin.
\end{abstract} purpose. 


\section{PENDAHULUAN}

Pola asuh atau parenting style menurut Kohn adalah sikap orang tua dalam berhubungan dengan anaknya yang dapat dilihat dari berbagai segi, antara lain dari cara orang tua memberikan pengaturan kepada anak, cara memberikan hadiah dan hukuman, cara orang tua menunjukkan otoritas dan cara orang tua memberikan perhatian, tanggapan terhadap keinginan anak (Toha, 1996). Pola asuh merupakan tata cara yang diterapkan orang tua dalam mengasuh, merawat, melindungi dan mendidik anak-anaknya.

Ada tiga jenis tipe pola asuh yaitu tipe otoriter, demokratis dan permisif. Pola asuh otoriter ditandai dengan adanya aturan-aturan yang kaku dari orang tua, kebebasan anak sangat dibatasi, orang tua memaksa dan memberikan hukuman fisik anak untuk berperilaku seperti yang diinginkannya. Pola asuh permisif ditandai dengan adanya kebebasan yang diberikan pada anak untuk berperilaku sesuai dengan keinginannya sendiri, tidak ada pengendalian atau pengontrolan serta tuntutan kepada anak karena pola ini tidak memberlakukan aturan yang ketat dan cenderung kurang memberikan bimbingan. Pola asuh demokratis ditandai dengan adanya sikap terbuka antara orang tua dengan anaknya (Yatim \& Irwanto, 1991).

Setiap pola asuh memiliki dampak yang berbeda bagi anak. Pola asuh otoriter membuat anak cenderung memiliki kedisiplinan dan kepatuhan yang semu akibat hilangnya kebebasan dan inisiatif sehingga anak menjadi tidak percaya diri pada kemampuannya. Pola asuh permissif dapat menjadikan anak kurang disiplin dengan aturan-aturan sosial yang berlaku. Sedangkan pola asuh demokratis menumbuhkan rasa tanggung jawab, mampu bertindak sesuai dengan norma yang ada (Anisa, 2005). Pola asuh orang tua sangat berpengaruh terhadap pembentukan karakter dan 
kecerdasan anak. Cara orang tua memperlakukan anak berpengaruh terhadap pembentukan karakter anak yang mana karakter tersebut terlihat dari perilaku anak (Trimuliana, Dhieni, \& Hapidin, 2019). Besarnya dampak pola asuh yang bagi perkembangan anak telah menjadi perhatian berbagai pihak. Dewasa ini banyak diselenggarakan program pendidikan keorangtuaan atau parenting dalam rangka memperbaiki pola asuh di masyarakat. Hal tersebut sesuai dengan pengertian parenting yang dikemukakan dalam Juknis Orientasi Teknis Peningkatan Program Parenting tahun 2011, program parenting adalah program dukungan yang ditunjukan kepada orang tua atau anggota keluarga yang lain agar semakin memiliki kemampuan dalam melaksanakan fungsi sosial dan pendidikan dalam hal mengasuh, merawat, melindungi, dan mendidik anaknya di rumah sehingga anak dapat tumbuh dan berkembang secara optimal, sesuai dengan usia dan tahap perkembangannya (Ganevi, 2013). Keberadaan program parenting di tengah masyarakat sangat bermanfaat dalam memperbaiki pola asuh orang tua karena orang tua membutuhkan penambahan pengetahuan yang dapat meningkatkan kemampuannya dalam mengasuh anak. Seseorang dengan kemampuan mengasuh yang baik lebih mampu memahami, berinteraksi dan mengontrol anak dengan lebih baik, sehingga setiap interaksi dengan anak merupakan media pembelajaran atau edukasi yang efektif bagi anak sehingga terbagun karakter, kecerdasan, kemandirian dan keharmonisan hubungan dalam keluarga terutama antara orang tua dan anak.

Salah satu upaya yang dilakukan pemerintah kota Banjarmasin untuk memperbaiki pengasuhan anak adalah dengan mengadakan program parenting yang dinamai dengan Sekolah Ibu dan Calon Ibu. Program Sekolah Ibu dan Calon Ibu Kota Banjarmasin diselenggarakan oleh Dinas Pemberdayaan Perempuan dan Perlindungan 
Anak (P3A) Banjarmasin bekerjasama dengan Pembina Kesejahteraan Keluarga (PKK) Banjarmasin. Sekolah Ibu yang diasuh oleh ibu walikota Hj. Siti Wasilah. Sekolah Ibu memiliki kurikulum yang disusun sebanyak enam kali pertemuan yang dilangsungkan satu kali dalam sebulan. Peserta tidak dipungut biaya dan sebaran peserta Sekolah Ibu terdiri dari berbagai kecamatan di lingkungan kota Banjarmasin. Sekolah Ibu merupakan salah satu ikhtiar membangun kemampuan pola asuh dalam keluarga melalui ibu untuk meningkatkan keharmonisan keluarga dan meminimalisir kekerasan pada perempuan dan anak di Kota Banjarmasin.

Penulis telah melakukan penelusuran terhadap penelitian-penelitian terdahulu tentang program parenting diantaranya penelitian (Yani Komariah, 2015) tentang efektivitas program parenting, penelitian (Ganevi, 2013) tentang pengaruh program parenting bagi keluarga ramah anak, penelitian (Kurniawan, 2017) tentang pengaruh program parenting terhadap karakter anak, penelitian (Novitasari, 2017) tentang hubungan program parenting dengan pola asuh serta penelitian yang dilaksanakan oleh (Sary, 2018) tentang pengaruh pola asuh terhadap kecerdasan interpersonal anak. Dari penelusuran tersebut, penulis tidak menemukan penelitian tentang perubahan pola asuh maupun tentang Program Sekolah Ibu dan Calon Ibu Kota Banjarmasin.

\section{METODE}

Penelitian ini merupakan studi lapangan dengan pendekatan kualitatif dengan objek penelitian perubahan pola asuh peserta Sekolah Ibu dan Calon Ibu yang dilihat dari indikator kontrol terhadap anak, respon terhadap keinginan dan kesalahan anak, serta pemberian reward dan punishment. Sedangkan subjek dalam penelitian ini adalah peserta Sekolah Ibu dan Calon Ibu angkatan kedua periode 13 Januari 2018 
sampai 21 Oktober 2018. Pengumpulan data dilakukan dengan teknik angket terbuka yang dibagikan kepada seluruh peserta yang berjumlah 41 orang. Sedangkan analisis data yang digunakan mengacu kepada Miles dan Huberman yakni adanya reduksi data, sajian data dan merumuskan kesimpulan.

\section{HASIL DAN PEMBAHASAN}

\section{Persepsi dan Pola Asuh}

Persepsi adalah suatu proses dimana individu melakukan pengorganisasian terhadap stimulus yang diterima dan menginterpretasikan, sehingga seseorang dapat menyadari dan mengerti apa yang diterima dan hal ini juga dapat di pengaruhi oleh pengalaman-pengalaman pada individu yang bersangkutan (Arifin \& dkk, 2017). Persepsi juga dapat didefinisikan sebagai pengalaman yang diterima seseorang tentang peristiwa yang diterimanya melalui alat indera, dan kemudian ditafsirkan menurut kemampuan kognitif masing-masing individu.(Daulay, 2014)

Proses terbentuk persepsi ada beberapa tahapan, yaitu: a) Stimulus atau Rangsangan, proses terbentuk persepsi diawal ketika individu dihadapkan pada suatu stimulus/rangsangan yang hadir dari lingkungannya; b) Registrasi, dimana suatu gejala fisik yang nampak berupa penginderaan dan syarat seseorang berpengaruh melalui panca indera yang dimiliknya. Seseorang dapat melihat dan mendengarkan informasi yang terkirim kepadanya, lalu mendaftar informasi yang terkirim tersebut kepadanya; c) Interpretasi, suatu aspek dari kognitif dari persepsi yang penting yaitu proses yang memberikan arti kepada stimulus yang sudah diterimanya. Proses interpretasi ini bergantung pada faktor pendalaman, motivasi, dan kepribadian seseorang (Thoha, 2003). 
Menurut Thoha (2003), faktor-faktor yang mempengaruhi persepsi seseorang adalah sebagai berikut: a) Faktor internal: perasaan, sikap dan karakteristik individu, prasangka, keinginan atau harapan, perhatian (fokus), proses belajar, keadaan fisik, gangguan kejiwaan, nilai dan kebutuhan juga minat, dan motivasi; b) Faktor eksternal: latar belakang keluarga, informasi yang diperoleh, pengetahuan dan kebutuhan sekitar, intensitas, ukuran, keberlawanan, pengulangan gerak, hal-hal baru dan familiar atau ketidak asingan suatu objek.

Persepsi anggota keluarga terhadap pola asuh sangatlah penting, karena persepsi tersebutlah yang mempengaruhi perilaku pengasuhan terhadap anak. Keluarga melaksanakan tanggung jawab sebagai orang tua dan mampu memenuhi tugas sebagai pendidik mempunyai peranan yang besar dalam mempengaruhi kehidupan seorang anak, terutama pada tahap awal maupun pada tahap-tahap kritisnya dan yang paling berperan sebagai pendidik anak-anaknya adalah ibu (Nawafilaty, 2020).

Pola asuh atau parenting style itu sendiri adalah tata cara orang tua dalam berinteraksi dan berkomunikasi dengan anak baik dalam rangka menjaga, mendidik serta merawat anaknya. Menurut Kohn pola asuh merupakan sikap orang tua dalam berhubungan dengan anaknya yang dapat dilihat dari berbagai segi, antara lain dari cara orang tua memberikan pengaturan kepada anak, cara memberikan hadiah dan hukuman, cara orang tua menunjukkan otoritas dan cara orang tua memberikan perhatian, tanggapan terhadap keinginan anak (Toha, 1996).

Pembagian tipe pola asuh menurut para ahli sangat beragam, dalam penelitian ini peneliti mengacu kepada pendapat Hourlock (Toha, 1996) yang mengemukakan bahwa tipe pola asuh ada tiga yakni permisif, demokratis dan otoriter. Selain 
Hourlock, pendapat serupa juga dikemukakan oleh Yatim dan Irwanto (1991, hlm. 96-97) yang membagi tipe pola asuh menjadi tiga, permisif, demokratis dan otoriter.

Pertama, pola asuh permisif ditandai dengan adanya kebebasan yang diberikan pada anak untuk berperilaku sesuai dengan keinginannya sendiri. Orang tua tidak memberikan aturan dan pengarahan kepada anak. Semua keputusan diserahkan kepada anak tanpa adanya pertimbangan orang tua. Pada tipe pola asuh permisif tidak ada pengendalian atau pengontrolan serta tuntutan kepada anak karena pola ini tidak memberlakukan aturan yang ketat dan cenderung kurang memberikan bimbingan. Anak diijinkan diberikan kebebasan penuh dan untuk membuat keputusan untuk dirinya sendiri, tanpa pertimbangan orang tua. Anak berperilaku menurut apa yang diinginkannya tanpa ada kontrol dari orang tua. Dalam pola asuh ini, perkembangan kepribadian anak menjadi tidak terarah, dan mudah mengalami kesulitan jika harus menghadapi larangan-larangan yang ada di lingkungannya. Dariyo juga mengatakan bahwa pola asuh permissif yang diterapkan orang tua, dapat menjadikan anak kurang disiplin dengan aturan-aturan sosial yang berlaku. Namun bila anak mampu menggunakan kebebasan secara bertanggung jawab, maka dapat menjadi seorang yang mandiri, kreatif, dan mampu mewujudkan aktualitasnya.

Kedua, pola asuh otoriter ditandai dengan adanya aturan-aturan yang kaku dari orang tua. Kebebasan anak sangat dibatasi, orang tua memaksa anak untuk berperilaku seperti yang diinginkannya. Bila aturan-aturan ini dilanggar, orang tua akan menghukum anak, biasanya hukuman yang bersifat fisik. Dampak pola asuh otoriter, anak cenderung memiliki kedisiplinan dan kepatuhan yang semu akibat hilangnya kebebasan dan inisiatif sehingga anak menjadi tidak percaya diri pada kemampuannya. 
Ketiga, pola asuh demokratis ditandai dengan adanya sikap terbuka antara orang tua dengan anaknya. Mereka membuat aturan-aturan yang disetujui bersama. Anak diberi kebebasan untuk mengemukakan pendapat, perasaan, dan keinginannya dan belajar untuk dapat menanggapi pendapat orang lain. Dalam pola asuh ini, anak tumbuh rasa tanggung jawab, mampu bertindak sesuai dengan norma yang ada. Pola asuh demokratis ini, di samping memiliki sisi positif dari anak, terdapat juga sisi negatifnya, di mana anak cenderung merongrong kewibawaan otoritas orang tua, karena segala sesuatu itu harus dipertimbangkan oleh anak kepada orang tua (Anisa, 2005).

Dalam praktiknya di masyarakat, tidak digunakan pola asuh yang tunggal, dalam kenyataan ketiga pola asuh tersebut digunakan secara bersamaan di dalam mendidik, membimbing, dan mengarahkan anaknya, adakalanya orang tua menerapkan pola asuh otoriter, demokratis dan permissif. Dengan demikian, secara tidak langsung tidak ada jenis pola asuh yang murni diterapkan dalam keluarga, tetapi orang tua cenderung menggunakan ketiga pola asuh tersebut. Pola asuh yang diterapkan orang tua cenderung mengarah pada pola asuh situasional, di mana orang tua tidak menerapkan salah satu jenis pola asuh tertentu, tetapi memungkinkan orang tua menerapkan pola asuh secara fleksibel, luwes, dan sesuai dengan situasi dan kondisi yang berlangsung saat itu.

Faktor-faktor yang mempengaruhi pola asuh orang tua menurut hurlock adalah karakteristik orang tua, yaitu: a) 1. Kepribadian. Setiap orang berbeda dalam tingkat energi, kesabaran, intelegensi, sikap dan kematangannya. Karakteristik tersebut akan mempengaruhi kemampuan orang tua untuk memenuhi tuntutan peran sebagai orang tua dan bagaimana tingkat sensifitas orang tua terhadap kebutuhan 
anak-anaknya.; b) Keyakinan. Keyakinan yang dimiliki orang tua mengenai pengasuhan akan mempengaruhi nilai dari pola asuh dan akan mempengaruhi tingkah lakunya dalam mengasuh anakanaknya.; c) Persamaan dengan pola asuh yang diterima, apabila orang tua merasa bahwa orang tua mereka dahulu berhasil menerapkan pola asuhnya pada anak dengan baik, maka mereka akan menggunakan teknik serupa dalam mengasuh anak, namun apabila mereka merasa pola asuh yang digunakan orang tua mereka tidak tepat, maka orang tua akan beralih ke teknik pola asuh yang lain.

\section{Perubahan Persepsi Pola Asuh Peserta Program Sekolah Ibu Dan Calon Ibu}

Pola asuh peserta sebelum mengikuti Sekolah Ibu dan Calon Ibu adalah sebagai berikut:

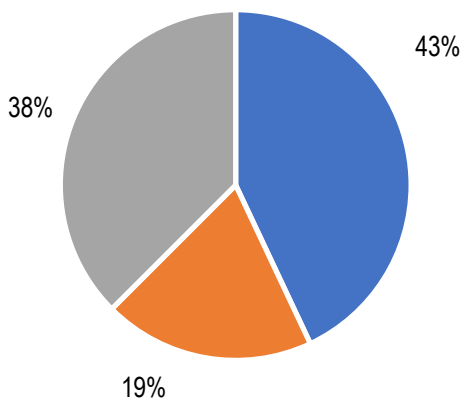

- Otoriter

- Permisif

- Demokratis

Gambar 1. Pola Asuh Sebelum Mengikuti Sekolah Ibu dan Calon Ibu

Berdsarkan gambar di atas, diketahui bahwa peserta menerapkan tipe pola asuh campuran yang didominasi tipe pola asuh otoriter. Sebelum mengikuti Sekolah Ibu, peserta mendisiplinkan anak dengan cara yang keras dan kasar yang merupakan ciri dari pola asuh otoriter. Menurut (Yatim \& Irwanto, 1991) bahwa pola asuh otoriter ditandai dengan adanya aturan-aturan yang kaku dari orang tua, kebebasan anak sangat dibatasi, orang tua memaksa dan memberikan hukuman fisik anak untuk 
berperilaku seperti yang diinginkannya. Mereka meyakini bahwa anak yang baik adalah anak yang sesuai dengan ekspektasi dan keinginan orang tua. Anak yang tidak sesuai dengan ekspektasi dan keinginan orang tua bukanlah anak yang baik. Sehingga orang tua berusaha keras untuk menjadikan anak sesuai dengan ekspektasi dan keinginannya dengan cara-cara yang otoriter seperti memaksa, memerintah, memarahi dan menghukum secara fisik. Seseorang dengan pola asuh otoriter selalu memaksakan aturan-aturan yang kaku, mengekang kebebasan anak, dan menghukum anak apabila aturan dan keinginannya tidak dipatuhi, biasanya hukuman bersifat fisik.

Sikap keras terutama ditunjukkan peserta pada cara mengontrol anak, cara merespon kesalahan anak, dan penerapan hukuman kepada anak. Menurut peserta mereka berpandangan bahwa orang tua berfungsi sebagai kontrol, untuk menjadikan anak yang baik diperlukan kontrol yang ketat. Kontrol terhadap anak direalisasikan dengan memberlakukan sejumlah aturan yang sepenuhnya dibuat oleh orang tua tanpa mempertimbangkan atau meminta pendapat dari anak. Anak harus menerima dan mematuhi aturan yang bersifat kaku tersebut tanpa perlawanan agar menjadi anak yang baik sesuai dengan ekspektasi dan keinginan orang tuanya. Jika diberikan kelonggaran anak akan menjadi malas, lalai, lamban bahkan menyepelekan dan melawan kepada orang tua yang artinya orang tua telah kehilangan wibawa dan otoritasnya.

Apabila anak melakukan kesalahan, umumnya orang tua kesulitan mengendalikan emosi, marah secara spontan dan seringkali mengmebikan hukuman fisik seperti mencubit, memukul dan lain sebagainya. Hal ini dilakukan untuk menimbulkan efek jera pada anak agar tidak mengulangi kesalahannya lagi. Ketika 
anak melakukan kesalahan kecil atau besar, sengaja atau tidak sengaja orang tua cenderung langsung marah, menuding dan menyalahkan tanpa menggali informasi atau kebenaran terlebih dahulu tentang peristiwa yang terjadi, apakah anak benarbenar bersalah atau tidak, karena orang tua selalu benar dan tau apa yang terbaik bagi anak-anaknya.

Setelah mengikuti Sekolah Ibu dan Calon Ibu, pola asuh peserta mengalami perubahan sebagai berikut:

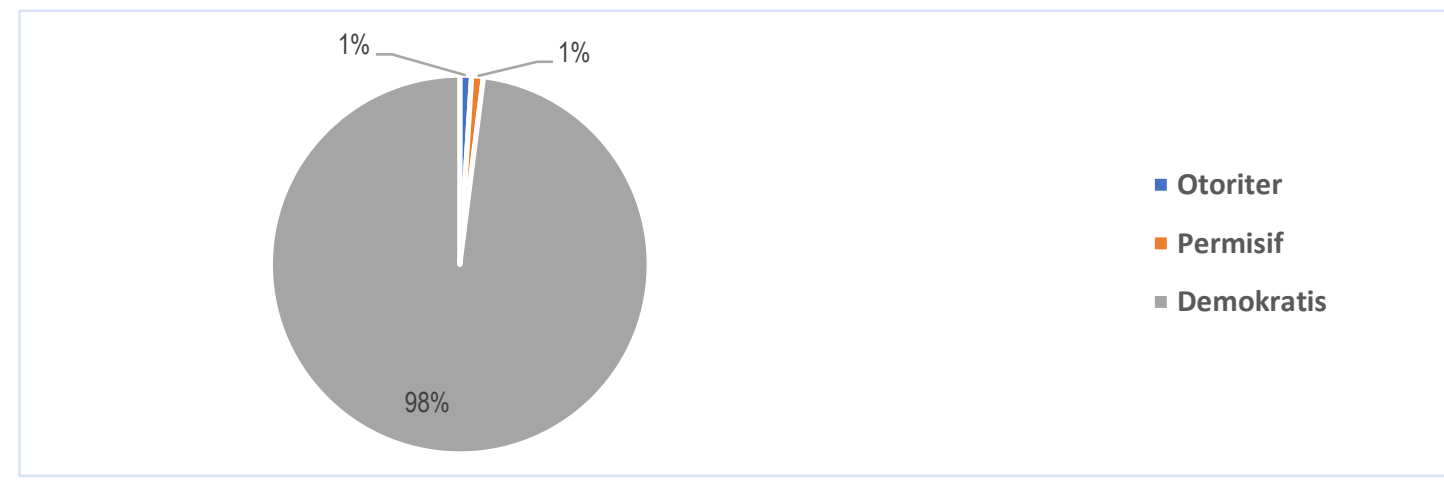

Gambar 2. Pola Asuh Setelah Mengikuti Sekolah Ibu dan Calon Ibu

Setelah mengikuti program Sekolah Ibu, terjadi perubahan pola asuh yang sangat signifikan dari otoriter menjadi demokratis. Setelah mengikuti Sekolah Ibu, kontrol terhadap anak tidak lagi kaku seperti sebelumnya, peserta melibatkan anak dalam membuat aturan/batasan yang disepakati bersama. Pengelolaan emosi menjdi lebih baik, jika anak melakukan tidak langsung marah dan menghukum melainkan terlebih dahulu mencari tahu kebenarannya untuk memastikan apakah anak salah atau tidak kemudian anak diajak berdiskusi tentang perbuatannya. Hukuman fisik ditinggalkan ada yang menggantinya dengan diganti dengan nasihat dan motivasi, ada yang mengganti ke hukuman yang dianggap mendidik seperti diberi hukuman 
tidak boleh menonton TV, disuruh menyiram tanaman, disuruh menghafal do'a atau pelajaran.

Sebagiannya lagi berpendapat bahwa anak tidak perlu dihukum, tidak dihukum bukan berarti anak dibiarkan melakukan kesalahan dan dibebaskan dari konsekuensi atas kesalahannya seperti pada tipe permisif. Anak tetap menerima konsekuensi sesuai dengan perbuatannya, misalnya ketika anak menumpahkan minuman karena sembarangan meletakkan gelasnya, maka konsekuensinya adalah anak bertanggung jawab membersihkan lantai dari bekas tumpahan airnya, ketika anak berbuat usil sehingga adiknya menangis maka konsekuensinya adalah dia harus meminta maaf dan membantu menenangkan adiknya, ketika anak lalai sehingga kehilangan jam tangannya di sekolah maka ia harus menerima konsekuensi tidak bisa memakai jam tangan lagi dan harus menabung lagi untuk membeli jam tangan baru.

Peserta memperoleh pengetahuan tentang parenting yang disampaikan selama mengikuti Sekolah Ibu dan Calon Ibu. Pengetahuan itu bukanlah salinan dari obyek dan juga bukan berbentuk kesadaran apriori yang sudah ditetapkan di dalam diri subyek, ia bentukan perseptual antara fikiran dan obyeknya menurut tinjauan kognitif. Saat seseorang memperoleh cara baru dalam merepresentasikan informasi secara mental, peserta Sekolah Ibu membangun kemampuan kognitif kita melalui tindakan yang termotivasi dengan sendirinya terhadap lingkungan (Ubaidillah, 2020).

Pengetahuan parenting yang didapatkan melalui Sekolah Ibu adalah stimulus yang sampai kepada peserta yang selanjutnya diinterpretasikan menjadi sebuah persepsi tentang pola asuh. Sehingga terjadi perubahan persepsi peserta terhadap pola asuh anak yang dianggap tepat dari otoriter menjadi demokratis. Hal ini 
membuktikan bahwa Sekolah Ibu dan Calon Ibu Kota Banjarmasin telah menjalankan perannya dengan baik sebagai program parenting yang ada di masyarakat sebagaimana yang dimaksud dalam Juknis Orientasi Teknis Peningkatan Program Parenting tahun 2011 bahwa program parenting adalah program dukungan yang ditunjukan kepada orang tua atau anggota keluarga yang lain agar semakin memiliki kemampuan dalam melaksanakan fungsi sosial dan pendidikan dalam hal mengasuh, merawat, melindungi, dan mendidik anaknya di rumah sehingga anak dapat tumbuh dan berkembang secara optimal, sesuai dengan usia dan tahap perkembangannya (Ganevi, 2013).

\section{KESIMPULAN}

Setelah mengikuti Sekolah Ibu dan Calon Ibu pola asuh peserta yang sebelumnya dominan otoriter berubah menjadi demokratis, artinya pendidikan parenting bagi orang dewasa yang dilaksanakan di Sekolah Ibu telah berhasil mengubah persepsi, tata cara, sikap dan perilaku dalam pengasuhan terhadap anak menjadi lebih baik. 


\section{REFERENSI}

Adawiah, R. (2017). Pola Asuh Orang Tua dan Implikasinya terhadap Pendidikan Anak. 7, 16.

Anisa, S. (2005). Kontribusi Pola Asuh Orang tua terhadap Kemandirian Siswa Kelas II SMA Negeri 1 Balapulang Kabupaten Tegal Tahun Pelajaran 2004/2005 (Skripsi). Universitas Negeri Semarang, Semarang.

Arifin, H. S., \& dkk. (2017). Analisis Faktor yang Mempengaruhi Persepsi Mahasiswa UNTIRTA Terhadap Keberadaan PERDA Syariah di Kota Serang. Jurnal Penelitian Komunikasi dan Opini Publik, Vol. 21, 88-101.

Daulay, N. (2014). Pengantar Psikologi dan Pandangan Al-Qur'an tentang Psikologi. Jakarta: Prenadamedia Group.

Een Novitasari. (2017). Hubungan Kualitas Program Parenting Dan Pola Asuh Orang Tua Dalam Keluarga: Studi Terhadap Orang Tua Peserta Program Parenting di Kelurahan Isola Kecamatan Sukasari Kota Bandung (Other, Universitas Pendidikan Indonesia). http://repository.upi.edu/33524/10/S_PLS_1305633_Appendix.pdf

Ganevi, N. (2013). Pelaksanaan Program Parenting Bagi Orang Tua Dalam Menumbuhkan Perilaku Keluarga Ramah Anak (Studi Deskriptif di Pendidikan Anak Usia Dini Al-Ikhlas Kota Bandung). Jurnal Pendidikan Luar Sekolah, Vol 9(2). Diambil dari https://ejournal.upi.edu/index.php/pls/article/ view/5425

Komariah, Y. (2015). Efektivitas Program Pelatihan Parenting Skill terhadap Peningkatan Pemahaman Orang Tua tentang Pola Asuh. Jurnal Bimbingan dan Konseling Islam UIN Sunan Ampel Surabaya, Vol 5, 66-91.

Kurniawan, H., \& Hermawan, R. (2017). Program Parenting Untuk Membentuk Karakter Anak Usia Dini Di Lembaga Pendidikan Anak Usia Dini. Aṣ-Ṣibyān: Jurnal Pendidikan Anak Usia Dini, 1(01), 29-39.

Nawafilaty, T. (2020). Pola Pengasuhan Alternative Dual Career Family Dalam Pemenuhan Kebutuhan Asih Anak. Journal of Childhood Education, 2(2). Diambil dari http://journalfai.unisla.ac.id/index.php/jce/article/view/62

Sary, Y. N. E. (2018). Relationship of Parenting with Child Interpersonal Intelligence in Wonokerto Village, Lumajang Regency. Jurnal Obsesi : Jurnal Pendidikan Anak Usia Dini, 2(2), 137-142-142. https://doi.org/10.31004/obsesi.v2i2.93

Thoha, M. (2003). Kepemimpinan Dalam Manajemen. Jakarta: PT. Raja Grafindo Persada.

Toha, C. (1996). Kapita Selekta Pendidikan Islam. Yogyakarta: Pustaka Pelajar. 
Trimuliana, I., Dhieni, N., \& Hapidin, H. (2019). Perilaku Religius Anak Usia 5-6 Tahun pada PAUD Model Karakter. Jurnal Obsesi : Jurnal Pendidikan Anak Usia Dini, 3(2), 570-577-577. https://doi.org/10.31004/obsesi.v3i2.251

Ubaidillah, U. (2020). Pengembangan Minat Belajar Kognitif Pada Anak Usia Dini. Journal of Childhood Education, 2(2). Diambil dari http://journalfai.unisla.ac.id/index.php/jce/article/view/66

Yatim, D. I., \& Irwanto. (1991). Kepribadian Keluarga dan Narkotika. Jakarta: Arcan. 